\title{
The Allelopathic Effect of Eucalyptus leaf Extract on Grass FORAGE SEED ${ }^{1}$
}

\author{
Efeito Alelopático de Extrato Foliar de Eucalipto em Sementes de Gramíneas Forrageiras
}

CARVALHO, F.P. ${ }^{2}$, MELO, C.A.D. ${ }^{2}$, MACHADO, M.S. ${ }^{2}$, DIAS, D.C.F.S. ${ }^{2}$, and ALVARENGA, E.M. ${ }^{2}$

\begin{abstract}
This study aimed to evaluate the allelopathic effect of various concentrations of an aqueous extract of eucalyptus leaves on Urochloa decumbens and Panicum maximum seeds. The extract was prepared from Eucalyptus urograndis leaves that were milled and mixed with distilled water in a 1:9 milled leaves: water ratio to obtain an extract with a defined concentration of $100 \%$. In addition, dilutions of $50 \%, 25 \%$ and $12.5 \%$ were prepared, and a $0 \%$ dilution was used as a control. The experiment followed a completely randomized design, with four replicates, each of 50 seeds of $U$. decumbens and 50 seeds of $P$. maximum, arranged on filter paper moistened with each concentration of extract in a Gerbox plastic box. The results demonstrated the allelopathic potential of $E$. urograndis aqueous extracts applied to the seeds of $U$. decumbens and $P$. maximum. The $50 \%$ and $100 \%$ concentrations of leaf extract most strongly inhibited the germination, vigor and seedling growth of $U$. decumbens and $P$. maximum. The germination speed index and the root length were the characteristics that were most affected by the potentially allelopathic substances contained in the eucalyptus extracts at all concentrations.
\end{abstract}

Keywords: Eucalyptus urograndis, Urochloa decumbens, Panicum maximum, agroforestry system, germination, seedling performance.

\begin{abstract}
RESUMO - Objetivou-se neste estudo avaliar o efeito alelopático de concentrações do extrato aquoso de folhas de eucalipto sobre sementes de Urochloa decumbens e Panicum maximum. $O$ extrato foi preparado utilizando folhas de Eucalyptus urograndis moidas, as quais foram colocadas em água destilada na proporção de 1:9, obtendo-se a concentração de 100\% e as diluições de 50\%, 25\%, 12,5\% e 0\% (testemunha). O ensaio foi montado em delineamento inteiramente casualizado, com quatro repetições de 50 sementes de $\boldsymbol{U}$. decumbens e P. maximum, dispostas sobre papel-filtro umedecido com as concentrações do extrato, em caixas do tipo gerbox. Os resultados indicam a existência de potencial alelopático de $\boldsymbol{E}$. urograndis sobre as espécies $\boldsymbol{U}$. decumbens $e$ P. maximum. Efeitos mais pronunciados na inibição da germinação e redução do vigor e do crescimento de plântulas de $\boldsymbol{U}$. decumbens $e \boldsymbol{P}$. maximum foram observados nas concentrações de $50 \%$ e $100 \%$ do extrato foliar de eucalipto. O indice de velocidade de germinação e o comprimento da radicula foram as características mais afetadas pelas substâncias potencialmente alelopáticas do extrato de eucalipto, em todas as concentrações.
\end{abstract}

Palavras-chave: Eucalyptus urograndis, Urochloa decumbens, Panicum maximum, sistemas agroflorestais, germinação, desempenho de plântulas.

\section{INTRODUCTION}

Agroforestry and silvopasture systems have been increasingly adopted in recent years as alternatives to traditional models of forestry and to facilitate the recovery and renewal of degraded pasture. These systems are attractive because they allow the amortization of the implementation costs through diversified production. These systems are considered to be multifunctional, as they allow the intensification of production through

1 Recebido para publicação em 26.1.2015 e aprovado em 26.2.2015.

2 Universidade Federal de Viçosa, Viçosa, Minas Gerais, Brasil; <felipepaolinelli@yahoo.com.br>. 
the integrated management of natural resources without environmental degradation (Porfirio da Silva, 2006). Furthermore, both systems can support forestry production combined with other products and according to the basic principles of sustainable management (Oliveira Neto et al., 2007).

The species of the genus Eucalyptus used in forestry are notable for their rapid growth and excellent adaptation to many types of environmental conditions and for the versatile uses of their wood (Oliveira Neto et al., 2010). The forage crops most widely used in agroforestry systems are species belonging to the genera Urochloa and Panicum. These species are preferred because of their moderate tolerance to shade, their traditional role in agriculture and their nutritional quality (Andrade et al., 2001).

Although eucalyptus is a rapidly growing tree, it is vulnerable to competition from weeds, primarily during the first two years after planting (Toledo et al., 2003). Thus, frequent weeding is required (Toledo et al., 2001). In monoculture, as well as in multifunctional systems, weed control is performed with chemical and mechanical methods, separately or in combination.

Urochloa decumbens and Panicum maximum are desirable components in agroforestry systems. However, these species can become problematic if they are not well managed. They can have significant impacts as weeds because they are highly aggressive and show strong competitive ability during the initial stages of growth of eucalyptus (Toledo et al., 2000; Cruz et al., 2010). Thus, appropriate management measures should be adopted to reduce the effects of competition among species.

A forestry practice widely used in integrated systems is artificial pruning. This practice is followed to improve stem form and wood quality. Moreover, it opens a route for solar radiation to reach the understory, where the forage plants occur. After pruning, the branches and leaves are allowed to remain among the rows of eucalyptus. It is believed that these materials can produce allelopathic effects on weeds or forage plants. Such effects may involve, e.g., the abnormal growth of the seedlings or the inhibition of seed germination. These allelopathic effects ensure that the development of the eucalyptus is free from interference.

Due to the complexity of these mixed systems, knowledge about the interactions of their components is essential, and allelopathy is an important factor that should be investigated. Allelopathy is defined as an inhibitory or beneficial effect, direct or indirect, of a plant on another plant through the production and exudation of chemical compounds (Rice, 1984).

Many previous studies have demonstrated the allelopathic effects of Eucalyptus spp. on various crops (Alves et al., 1999; Willis, 1999; Ferreira \& Áquila, 2000; Ferreira et al., 2007; Yamagushi et al., 2011). However, there is no information about the allelopathic effects of Eucalyptus spp. on forage species, and studies of allelopathic interactions in agroforestry systems are lacking. Accordingly, this study aims to address these topics.

The objective of this study was to evaluate the allelopathic effects of concentrations of an aqueous extract of eucalyptus leaves on Urochloa decumbens and Panicum maximum.

\section{MATERIALS AND METHODS}

Leaves of one-year-old Eucalyptus urograndis were collected from the base of the canopy of 20 trees. The leaves were dried in a forced-air circulation drying oven $\left(65 \pm 3{ }^{\circ} \mathrm{C}\right)$ for 48 hours and ground in an analytical mill. A 75-gram sample of the ground leaves was then collected. A total of $675 \mathrm{~mL}$ of distilled water was added to the sample to obtain a solution with a 1:9 ratio of ground leaves to water. The solution was allowed to rest for 24 hours and then passed through filter paper to obtain an extract containing water-soluble compounds. This extract was a $100 \%$ stock solution containing the extracted compounds and represented the potential amount able to influence one grass seed on field. Aliquots from this solution were diluted to obtain concentrations of $50 \%, 25 \%$ and $12.5 \%$. The effects of these concentrations were compared to the effects of a distilled-water control (designated 0\%). 
Urochloa decumbens and Panicum maximum seed were used (germination below $80 \%$ ). A total of 50 seeds were placed on germitest paper in a plastic Gerbox. At each concentration, the paper was moistened with the selected test solution to achieve a weight of 2.5 times the original paperweight. The experiments were performed in a germinator at $20{ }^{\circ} \mathrm{C}$ for 16 hours (without light) and at $35{ }^{\circ} \mathrm{C}$ for eight hours (with light) per day according to the Regras para Análise de Sementes (RAS) specifications (Brasil, 2009).

Normal seedlings were counted daily up to the seventh and tenth day for $U$. decumbens and $P$. maximum, respectively. The germination speed index (GSI) was calculated according to Maguire (1962), and normal seedlings resulting from the first germination were counted. The radicle length and shoot length of ten plants were evaluated for each replication on the first germination count with a digital caliper.

A second trial was conducted simultaneously with the first trial to minimize possible contamination. The germination percentages resulting from the tested concentrations of aqueous extract of eucalyptus leaves were evaluated. The normal seedlings of both species were counted at 7 , 14 and 21 days after the application of the treatments. For $P$. maximum only, a further count was performed at 28 days. The final count was determined according to Brasil
(2009). The normal seedlings were separated, placed in kraft paper bags and dried in an oven with forced air circulation at $70{ }^{\circ} \mathrm{C}$. The weight of dry matter per seedling was then determined. The percentage of abnormal seedlings was determined at the end of the trial.

A completely randomized experimental design was used. The design comprised five extract concentrations $(0,12.5,25,50$ and $100 \%$ ) and four replications. An analysis of variance $(p<0.05)$ and a regression analysis were used to analyze the data. Equations and models were selected based on the coefficient of determination, the regression coefficient and the biological phenomenon to be analyzed.

\section{RESULTS AND DISCUSSION}

All analyzed variables showed quadratic or linear responses to the concentrations of the test extracts. The initial count of normal seedlings of both species in the germination test showed a quadratic response to concentration, with an initial growth increase at lower concentrations and a drastic reduction of the percentage of normal seedlings at higher concentrations (Figure 1). Based on the fitted curves, the promotion of growth of $U$. decumbens and $P$. maximum by the extracts extended to concentrations of $24.58 \%$ and $13.66 \%$, respectively. The growth then decreased at higher concentrations.
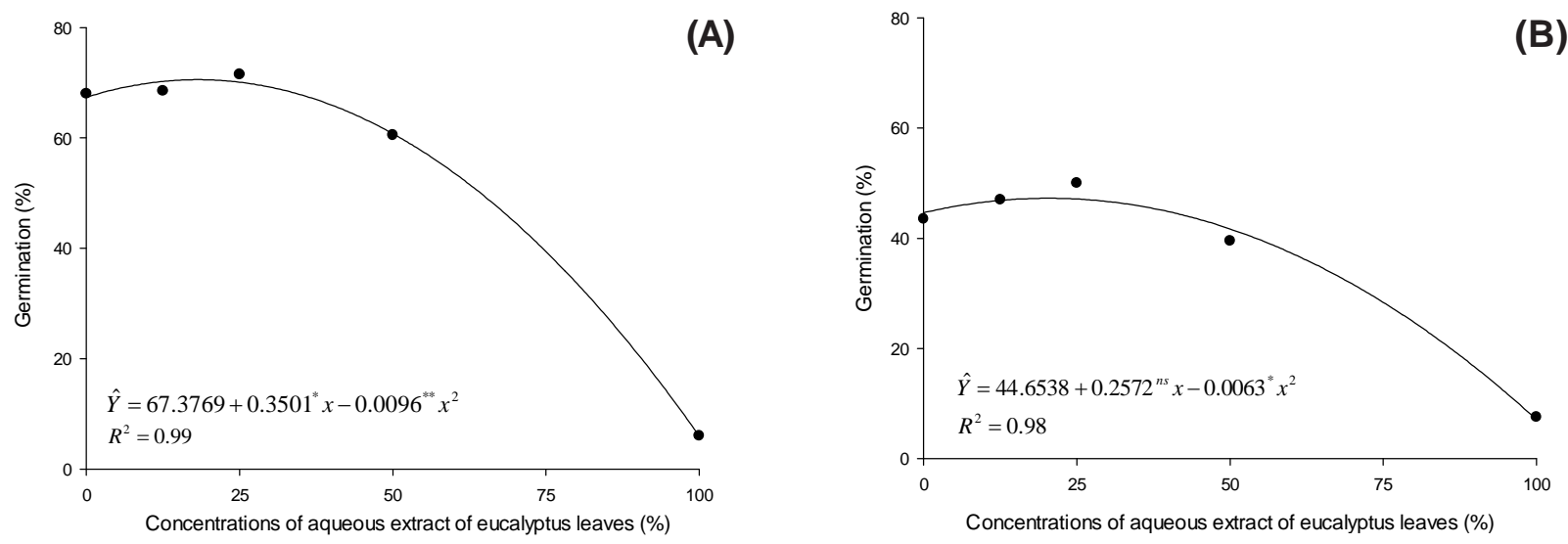

ns, ** and * non significant, significant to 1 and to $5 \%$ of probability, respectively.

Figure 1 - The percentage of normal seedlings of Urochloa decumbens (A) and Panicum maximum (B) counted daily up to the seventh and tenth day, respectively. 
Eucalyptus species are known to produce inhibitory substances that affect the growth of other plant species (Rizvi et al., 1999). These allelopathic substances are exuded by the eucalyptus plants and can benefit or damage the growth of other plants (Sobrero et al., 2004). Souza Filho \& Alves (2000) evaluated the allelopathic potential of acapu (Vouacapoua americana) plants against two types of pasture weeds, malícia (Mimosa pudica) and malva (Urena lobata). The results of their study showed that germination and primary root length were decreased by the treatment. Bedin et al. (2006) found that aqueous extracts of fresh and dry leaves of Eucalyptus citriodora had no effect on tomato seed germination. Tomato plants are sensitive to allelopathic substances. However, the concentrations of the extracts used in the Bedin et al. (2006) study were lower than the concentrations used in the current study and did not show allelopathic inhibition of seeds.

The final counts of germination showed that the tested extracts had negative effects on both forage species. Based on the fitted curves, germination increased at concentrations up to $18.23 \%$ and $20.41 \%$, respectively, for $U$. decumbens and $P$. maximum. Germination then decreased to $6.39 \%$ in $U$. decumbens and $7.37 \%$ in $P$. maximum at an extract concentration of $100 \%$ (Figure 2). $U$. decumbens was found to be sensitive to an aqueous extract of Vernonia polyanthes, which reduced germination to

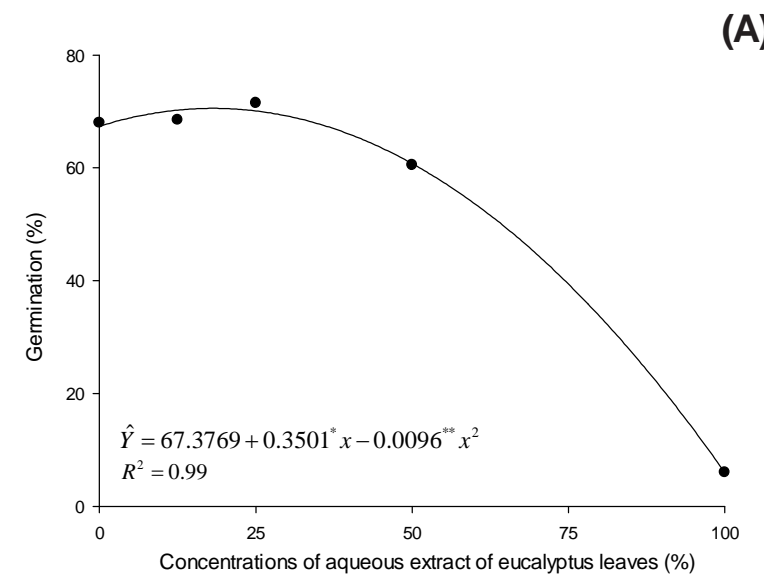

$69.59 \%$ at a concentration of $100 \%$ (Marcos Filho et al., 1996). An understanding of allelopathic effects is important to determine suitable husbandry practices and management for crops to prevent the interference of allelopathic substances with crop growth and production (Gatti et al., 2004).

In the current study, the tested extracts produced an increase in abnormal seedlings. The percentage of abnormal seedlings increased with increasing concentrations of the extract. $U$. decumbens showed an increase in the percentage of abnormal seedlings at extract concentrations greater than $8.99 \%$. The percentage of abnormal seedlings in $U$. decumbens was greater than $60 \%$ at a $100 \%$ concentration of eucalyptus extract, whereas the percentage of abnormal seedlings in $P$. maximum was greater than $35 \%$ at this concentration (Figure 3).

The germination speed index showed a greater decrease in both forage species. The index decreased to values near zero in $U$. decumbens and $P$. maximum as the concentration of the extract increased (Figure 4). Germination is less sensitive to allelopathic substances than seedling growth, and allelopathic substances can produce abnormal characteristics in seedlings. Root necrosis is a common symptom associated with allelopathic effects. An increased number of abnormalities were observed at higher concentrations of the eucalyptus extract.

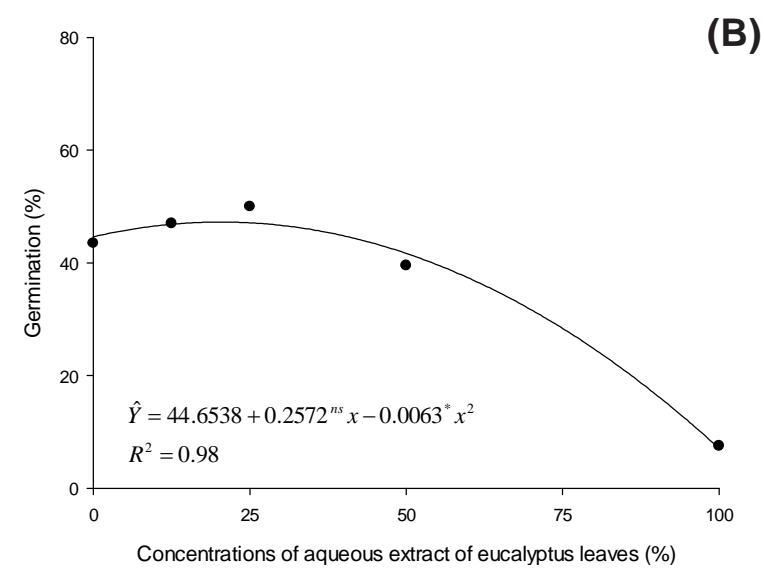

ns, ** and * non significant, significant to 1 and $5 \%$ of probability, respectively.

Figure 2 - The germination percentage of Urochloa decumbens (A) and Panicum maximum (B) seed resulting from concentrations of aqueous extract of eucalyptus leaves. 

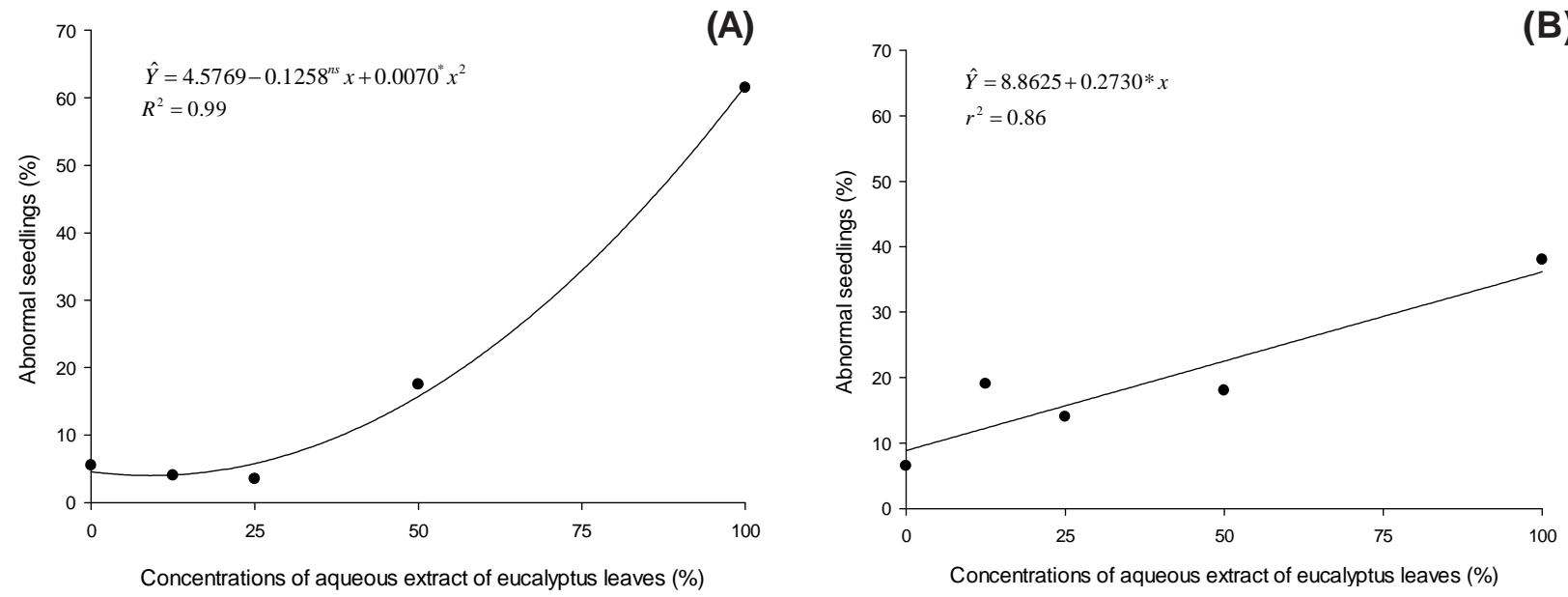

ns, ** and * non significant, significant to 1 and $5 \%$ of probability, respectively.

Figure 3 - The abnormal seedlings percentage of Urochloa decumbens (A) and Panicum maximum (B) resulting from concentrations of aqueous extract of eucalyptus leaves.
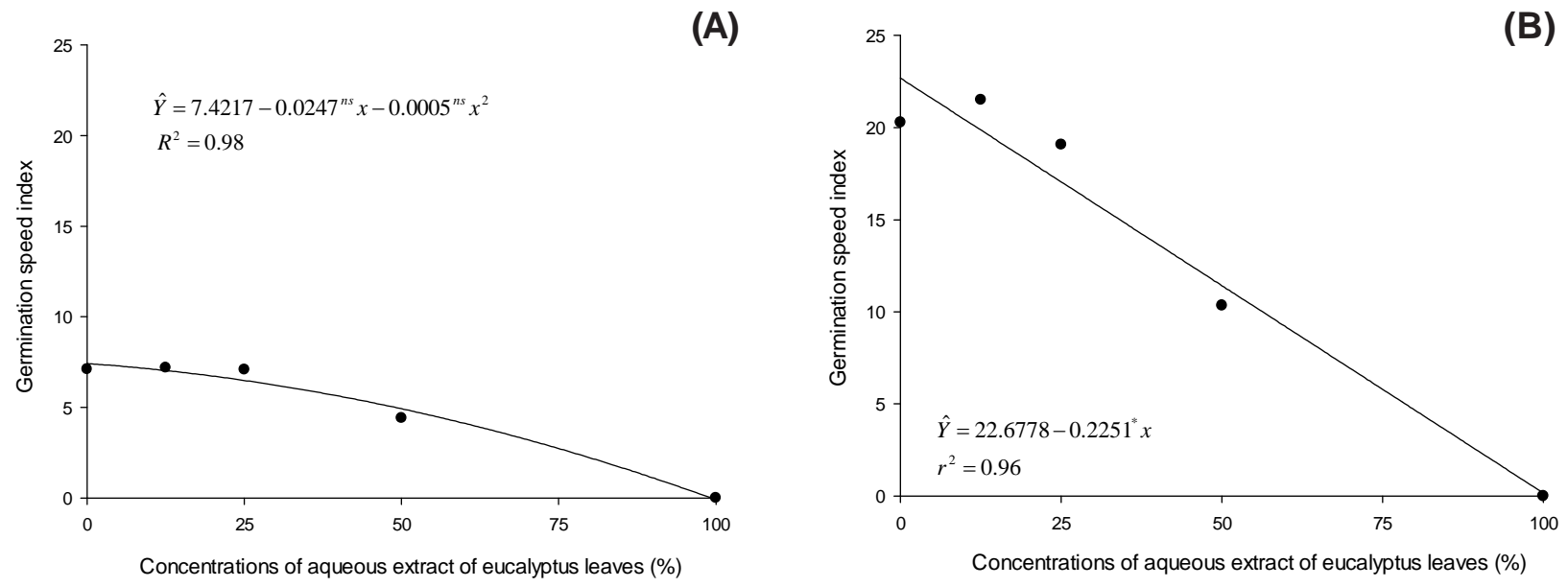

ns, ** and * non significant, significant to 1 and $5 \%$ of probability, respectively.

Figure 4 - The germination speed index of Urochloa decumbens (A) and Panicum maximum (B) seeds resulting from concentrations of aqueous extract of eucalyptus leaves.

Generally, necroses were observed in the distal region of the roots, and the roots were thicker or exhibited signs of atrophy. According to Jacobi \& Ferreira (1991), the inhibition of seedling growth after germination is, in an ecological context, a more efficient mechanism than the prevention of germination because it can actually eliminate the affected species.

The shoot length of $U$. decumbens seedlings was positively affected by the eucalyptus extract. The maximum length obtained was $2.97 \mathrm{~cm}^{\text {seedling }}{ }^{-1}$, at a concentration of $58 \%$ (Figure 5A). However, shoot length in $P$. maximum and $U$. decumbens was stimulated at extract concentrations up to $50 \%$. A decrease of $71.4 \%$ in shoot growth relative to the control was obtained with the 100\% concentration of the extract (Figure 5B). Yamagushi et al. (2011) showed that an aqueous extract of Eucalyptus globulus influenced the initial growth of crops, inhibiting the growth of shoots and roots. 
(A)

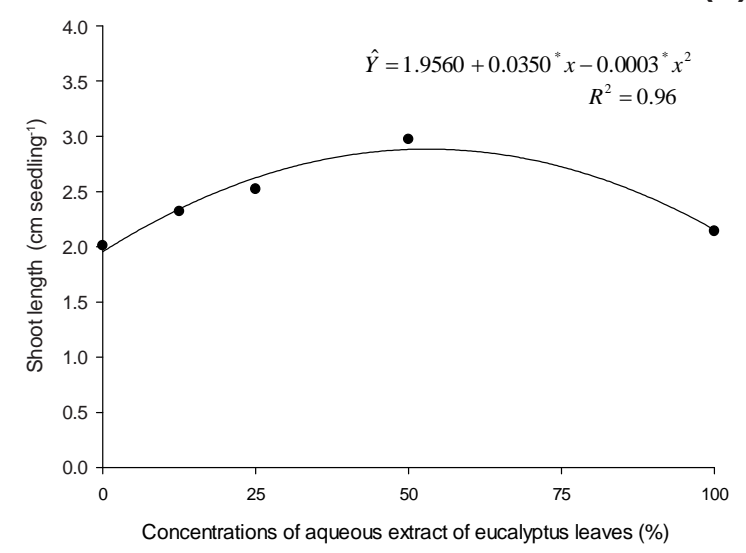

(B)

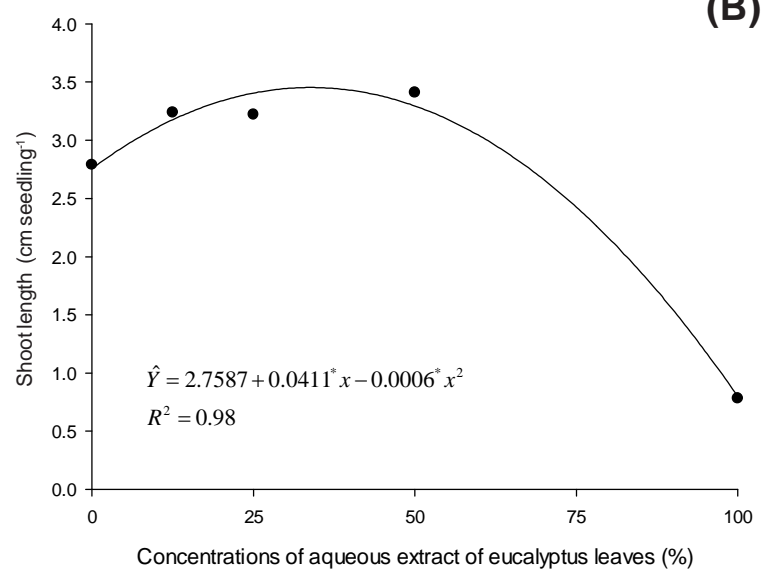

ns, ** and * non significant, significant to 1 and $5 \%$ of probability, respectively.

Figure 5 - The shoot length of seedlings of Urochloa decumbens (A) and Panicum maximum (B) seeds resulting from concentrations of aqueous extract of eucalyptus leaves.

Increased extract concentrations produced more marked results.

The eucalyptus extract showed potential allelopathic effects on the radicle length of both forage species (Figure 6). U. decumbens seedlings showed a negative linear effect, with reductions in radical length of approximately $10,19,37$ and $74 \%$ at concentrations of 25, 50, 75 and 100\%, respectively (Figure 6A). The radicle length of $P$. maximum was affected negatively. The decrease was up to $3.56 \mathrm{~cm}$ seedling $^{-1}(85 \%)$ at an extract concentration of $100 \%$ (Figure 6B).

The current study and previous studies found allelopathic effects on germination, on vigor and on seedling growth. Several studies have found that the damage to seedling growth was more severe than the damage to seed germination (Bedin et al., 2006; Iganci et al., 2006). However, other studies have found that extracts of leaves of species used in forestry inhibit the germination, germination speed index and growth of crops (Jacobi \& Ferreira, 1991; Goetze \& Thomé, 2004). No previous studies have addressed the allelopathic potential of eucalyptus extract in forage species, and research is lacking on the use of the associated allelopathic compounds in agroforestry systems.

A regression analysis found a quadratic relationship between seedling dry matter in both forage species and increases in the concentration of the aqueous extract of eucalyptus leaves. Negative effects were only found up to 75 and $50 \%$ concentration in $U$. decumbens and $P$. maximum, respectively (Figure 7).

A stimulatory effect at low concentrations of extract and a toxic effect at high concentrations, as observed in several variables in this study, may be related to a phenomenon termed hormesis. This phenomenon was first discussed by Southam \& Erlick (1943), who showed that certain substances that are toxic at high concentrations can stimulate or promote growth at low concentrations. The hormetic effects of pesticide applications on crops are well known (Wagner et al., 2003; Cedergreen et al., 2004; Cedergreen et al., 2005; Silva et al., 2012). According to Duke et al. (2006), allelochemicals are known to induce hormesis. Exposure to allelochemicals can involve various feedback mechanisms whose behavior depends on the specific substance and on the species subjected to the exposure. The mechanism can be a physiological effect, e.g., an increase in growth to facilitate escape from a chemical stressor, as verified in this study. Allelochemicals can alter the allocation of resources and reduce the performance of plants in their environment, directly influencing competition among species in an ecosystem 

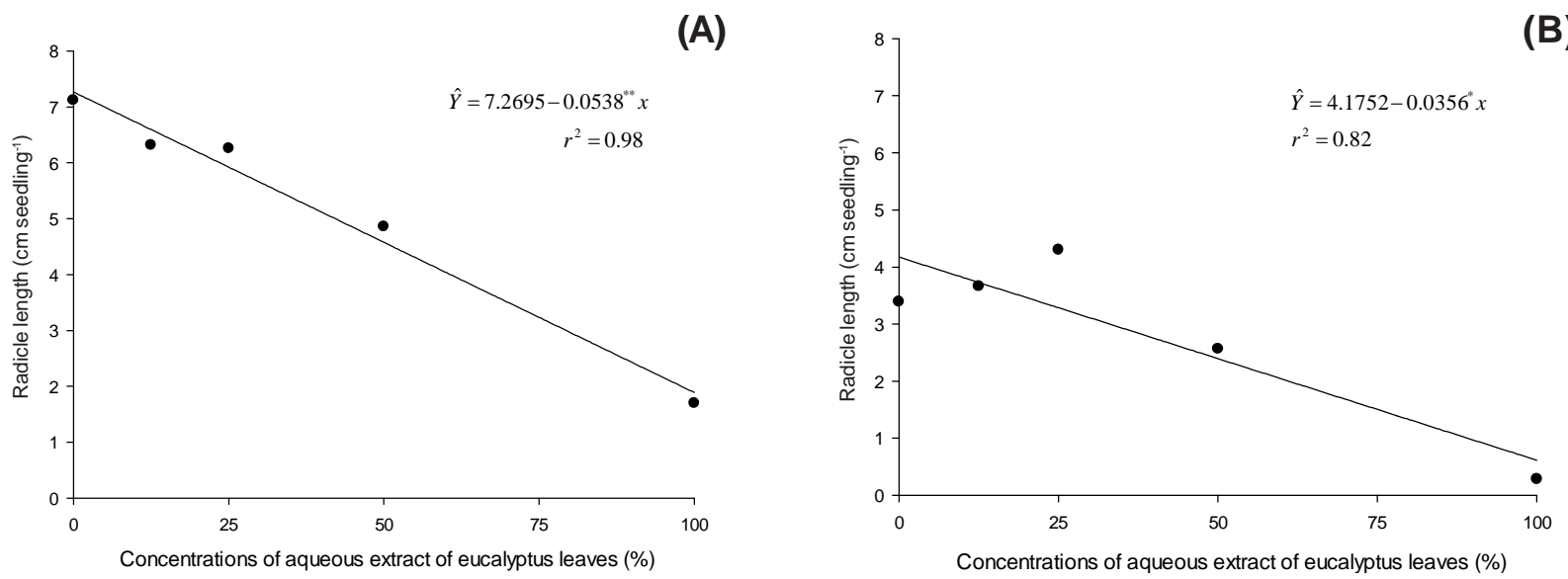

ns, ** and * non significant, significant to 1 and $5 \%$ of probability, respectively.

Figure 6 - The radicle length of seedlings of Urochloa decumbens (A) and Panicum maximum (B) seeds resulting from concentrations of aqueous extract of eucalyptus leaves.
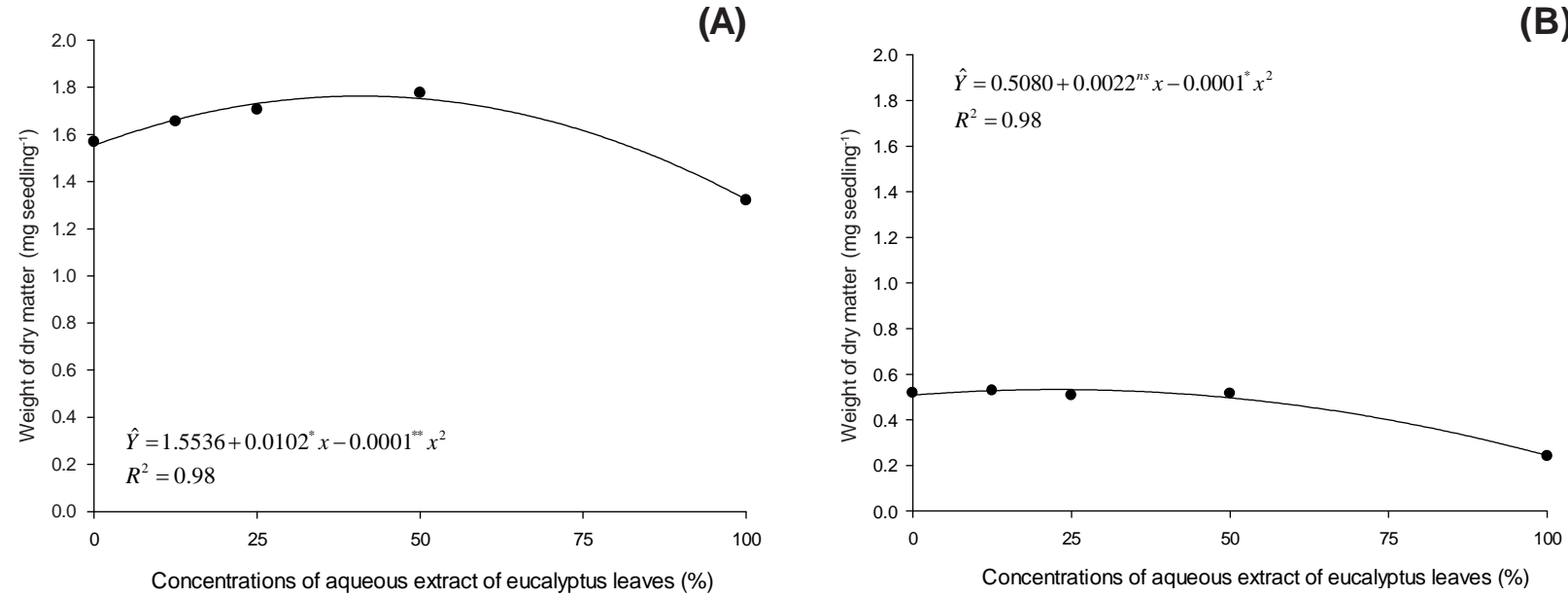

ns, ** and * non significant, significant to 1 and $5 \%$ of probability, respectively.

Figure 7 - The weight of dry matter per seedlings of Urochloa decumbens (A) and Panicum maximum (B) resulting from concentrations of aqueous extract of eucalyptus leaves.

(Duke et al., 2006). Accordingly, an improved understanding of allelopathy can improve the potential use of allelopathic substances to control crops in weed management.

The results of this study show that the potential allelopathic effects of an aqueous extract of the leaves of E. urograndis can influence all the evaluated characteristics of germination and initial seedling growth. Except the shoot growth of $U$. decumbens did not showed different, despite a growth with $50 \%$ of extract concentration. The most marked effects on the inhibition of germination, the reduction of vigor and the reduction of the initial growth of seedlings of $U$. decumbens and $P$. maximum were observed for $50 \%$ and $100 \%$ concentrations of the eucalyptus extract. Among the evaluated characteristics, the germination speed index and radicle length were most negatively affected by the potentially allelopathic substances contained in all concentrations of the eucalyptus extract. 


\section{ACKNOWLEDGMENTS}

The authors thank FAPEMIG (The Minas Gerais State Foundation for Research) and CNPq (The Brazilian National Counsel for Research and Development) for their financial support to perform this work.

\section{LITERATURE CITED}

ANDRADE, C. M. S., et al. Fatores limitantes ao crescimento do capim-tanzânia em um sistema agrossilvipastoril com eucalipto, na região dos Cerrados de Minas Gerais. R. Bras. Zootec., v. 30, n. 4, p. 1178-1185, 2001.

ALVES, P. L. C. A.; TOLEDO, R. E. B.; GUSMAN, A. B. Allelopathic potential of Eucalyptus spp. In: NARWAL, S. S. (Ed.). Allelopathy Update. Enfield: Science Pub., 1999. p. 131-148.

BEDIN, C. et al. Efeito alelopático de extrato de Eucalyptus citriodora na germinação de sementes de tomate (Lycopersicum esculentum M.). R. Cient. Eletr. Agron., v. 5, n. 10, dezembro 2006.

BRASIL. Ministério da Agricultura e Reforma Agrária, Departamento Nacional de Produção Vegetal. Divisão de Sementes e Mudas. Regras para análise de sementes. Brasília: 2009. 398 p.

CEDERGREEN, N.; STREIBIG J. C.; SPLIID, N. H. Species specific sensitivity of aquatic macrophytes towards herbicides. Ecotoxicol. Environ. Safety, v. 58, n. 3, p. 314-323, 2004.

CEDERGREEN, N.; RITZ, C.; STREIBIG, J. C. Improved empirical models describing hormesis. Environ. Toxicol. Chem., v. 24, n. 12, p. 3166-3172, 2005.

CRUZ, M. B. et al. Capim-colonião e seus efeitos sobre o crescimento inicial de clones de Eucalyptus x urograndis. Ci. Flor., v. 20, n. 3, p. 391-401, 2010.

DUKE, S. O. et al. Hormesis: is it an important factor in herbicide use and allelopathy? Outl. Pest Manage., v. 17, n. 1, p. 29-33, 2006.

FERREIRA, A. G.; ÁQUILA, M. E. A. Alelopatia: uma área emergente da ecofisiologia. R. Bras. Fisiol. Veg., v. 12, p. 175-204, 2000. (Edição Especial)

FERREIRA, M. C.; SOUZA, J. R. P.; FARIA, T. J. Potenciação alelopática de extratos vegetais na germinação e no crescimento inicial de picão-preto e alface.

Ci. Agrotecnol., v. 31, n. 4, p. 1054-1060, 2007.
GATTI, A. B.; PEREZ, S. C. J. G. A.; LIMA, M. I. S. Efeito alelopático de Aristolochia esperanzae O. Kuntze na germinação e no crescimento de Lactuca sativa L. e Raphanus sativus L. Acta Bot. Bras., v. 18, n. 3, p. 459-472, 2004.

GOETZE, M.; THOMÉ, G. C. H. Efeito alelopático de extratos de Nicotiana tabacum e Eucalyptus grandis sobre a germinação de três espécies de hortaliças. R. Bras. Agroci., v. 10, n. 1, p. 43-50, 2004.

IGANCI, J. R. V. et al. Efeito do extrato aquoso de diferentes espécies de boldo sobre a germinação e índice mitótico de Allium cepa L. Arq. Inst. Biol., v. 73, n. 1, p. 79-82, 2006.

JACOBI, U. S.; FERREIRA, A. G. Efeitos alelopáticos de Mimosa bimucronata (DC) sobre espécies cultivadas. Pesq. Agropec. Bras., v. 26, n. 7, p. 935-943, 1991.

MAGUIRE, J. D. Speed of germination-aid in selection evaluation for seedling emergence and vigour. Crop Sci., v. 2, n. 1, p. 176-177, 1962.

MARCOS FILHO, A. P. S.; RODRIGUES, L. R. A.; RODRIGUES, T. J. D. Efeitos de extratos aquosos de assapeixe sobre a germinação de três espécies de braquiária. Planta Daninha, v. 14, n. 2, p. 93-101, 1996.

OLIVEIRA NETO, S. N.; REIS, G. G. Eucalipto: as questões ambientais e seu potencial para Sistemas Agrossilvipastoris. In: FERNADES, E. N. et al. (Org.). Sistemas agrossilvipastoris na América do Sul: desafios e potencialidades. Juiz de Fora: Embrapa Gado de Leite, 2007. p. 245-282.

OLIVEIRA NETO, S. N. et al. Sistema Agrossilvipastoril: integração lavoura pecuária e floresta. Viçosa, MG: SIF, 2010. $190 \mathrm{p}$.

PORFÍRIO DA SILVA, V. Introdução de árvores madeiráveis em pastagens: algumas considerações e procedimentos mínimos. In: WORKSHOP SOBRE PTENCIAL DOS SISTEMAS SILVIPASTORIS NO DESENVOLVIMENTO DE MODELOS SUSTENTÁVEIS DE EXPLORAÇÃO PECUÁRIA, 2006, Juiz de Fora. Anais... Juiz de Fora: Embrapa Gado de Leite, 2006.

RICE, E. L. Allelopathy. New York: Academic Press, 1984. $422 \mathrm{p}$.

RIZVI, S. J. H. et al. Allelopathic interactions in agroforestry systems. Crit. Rev. Plant Sci., v. 18, n. 6, p. 773-796, 1999.

SILVA, H. C. et al. Efeito hormese de glyphosate em feijoeiro. Pesq. Agropec. Trop., v. 42, n. 3, p. 295-302, 2012.

SOBRERO, M. T.; OCHOA, M. C.; CHAILA, S. Potencial alelopático de Wedelia glauca: efeito sobre espécies hortículas. Planta Daninha, v. 22, n. 1, p. 71-75, 2004. 
SOUTHAM, C. M.; ERLICH, J. Effects of extract of western red-cedar heartwood on certain wood-decaying fungi in culture. Phytopathology, v. 33, n. 6, p. 517-524, 1943.

SOUZA FILHO, A. P. S.; ALVES, S. M. Potencial alelopático de plantas de acapu (Vouacapoua americana): Efeitos sobre plantas daninhas de pastagens. Planta Daninha, v. 18, n. 3, p. 435-441, 2000.

TOLEDO, R. E. B. et al. Efeito das faixas de controle do capim-braquiária (Brachiaria decumbens) no desenvolvimento inicial de plantas de eucalipto. Planta Daninha, v. 18, n. 3, p. 383-393, 2000.

TOLEDO, R. E. B. et al. Efeito da densidade de plantas de Brachiaria decumbens sobre o crescimento inicial de mudas de Eucalyptus grandis W.Hill ex Maiden. Sci. For., n. 60, p. 109-117, 2001.
TOLEDO, R. E. B. et al. Períodos de controle de Brachiaria sp. e seus reflexos na produtividade de Eucalyptus grandis. Sci. For., n. 63, p. 221-232, 2003.

WAGNER, R., KOGAN, M.; PARADA, A. M. Phytotoxic activity of root absorbed glyphosate in corn seedlings (Zea mays L.). Weed Biol. Manag., v. 3, n. 4, p. 228-232, 2003.

WILLIS, R. Australian studies on allelopathy in Eucalyptus: A review. In: INDERJIT; DAKSHINI, K. M. M.; FOY, C. L. (Ed.). Principles and practices in plant ecology. Boca Raton: CRC Press, 1999. p. 201-219.

YAMAGUSHI, M. Q.; GUSMAN, G. S.; VESTENA, V. Efeito alelopático de extratos aquosos de Eucalyptus globulus Labill. e de Casearia sylvestris Sw. sobre espécies cultivadas. Ci. Agr., v. 32, n. 4, p. 1361-1374, 2011. 